\title{
Bazal Vasküler Tonusun Düzenlenmesinde Rol Alan Mekanizmaların Sıçan Torasik Aort Modelinde İncelenmesi
}

\author{
Serdar ŞAHINTÜRK, Naciye İŞBİL \\ Bursa Uludağ Üniversitesi Tıp Fakültesi, Fizyoloji Anabilim Dalı, Bursa.
}

\section{ÖZET}

Bu çalışmada, endotelyal nitrik oksit sentaz (eNOS)/nitrik oksit (NO), siklooksijenaz (COX), AMP ile aktive olan protein kinaz (AMPK), mitojen ile aktive edilen protein kinaz (MAPK) ve apelin reseptörü (APJ) sinyal ileti yolakları ile potasyum kanallarının vasküler tonus üzerindeki etkisinin belirlenmesi amaçlandı. Wistar Albino erkek sıçanların torasik aortlarından elde edilen 4 mm'lik damar halkaları izole organ banyosu sistemine yerleştirildi. Damar gerimi 1 gram olarak ayarlandı. Sinyal ileti yolaklarının ve potasyum kanallarının bazal damar tonusu üzerindeki etkilerini belirlemek için 1 saatlik dengelenme periyodunu takiben inhibitör madde uygulamaları yapıldı. İnhibitör madde uygulamalarından önceki ve sonraki periyodlardaki gerim değerleri kaydedildi. N $\omega$-Nitro-L-arginin metil ester ve tetraetilamonyum uygulamaları bazal damar gerim değerlerinde istatistiksel olarak anlamlı düzeyde artışa neden oldu (sırasıyla: $p<0,001 ; p<0,05$ ). İndometazin ve dorsomorfin uygulamaları bazal damar gerim değerlerinde istatistiksel olarak anlamlı düzeyde azalmaya neden oldu ( $p<0,05)$. F13A ve U0126 uygulamaları bazal damar gerim değerlerinde istatistiksel olarak anlamlı düzeyde bir değișikliğe neden olmadı. Bu çalıșmanın verileri eNOS/NO, COX ve AMPK sinyal ileti yolakları ile potasyum kanallarının bazal vasküler tonus regülasyonunda önemli birer etken olduğunu göstermektedir. Buna karșın MAPK ve APJ sinyal ileti yolaklarının sıçan torasik aortundaki bazal vasküler tonus düzenlenmesinde önemli birer faktör olmadığı düşünülmektedir.

Anahtar Kelimeler: AMPK. COX. NO. Potasyum kanalı. Vasküler tonus.

Investigation of Mechanisms Involved in the Regulation of Basal Vascular Tone in a Rat Thoracic Aortic Model

\begin{abstract}
In this study, it was aimed to determine the effect of endothelial nitric oxide synthase (eNOS)/nitric oxide (NO), cyclooxygenase (COX), AMP-activated protein kinase (AMPK), mitogen-activated protein kinase (MAPK), and apelin receptor (APJ) signal-transducing pathways and potassium channels on vascular tone. $4 \mathrm{~mm}$ vascular rings obtained from the thoracic aorta of Wistar Albino male rats were placed in the isolated organ bath system. Vascular tension was adjusted to $1 \mathrm{gram}$. To determine the effects of signal-transducing pathways and potassium channels on basal vessel tone, inhibitors were administered after a 1-hour equilibration period. The tension values in the periods before and after the inhibitor application were recorded. N $\omega$-Nitro-L-arginine methyl ester and tetraethylammonium administrations caused a statistically significant increase in basal vascular tension values (in order: $p<0.001 ; p<0.05$ ). Indomethacin and dorsomorphin administrations caused a statistically significant decrease in basal vascular tension values $(\mathrm{p}<0.05)$. F13A and U0126 administrations didn't cause a statistically significant change in basal vascular tension values. The data of this study show that eNOS/NO, COX, and AMPK signal-transducing pathways and potassium channels have significant effects on the regulation of basal vascular tone. On the other hand, it is thought that MAPK and APJ signaling pathways aren't important factors in the regulation of basal vascular tone in the rat thoracic aorta.
\end{abstract}

Key Words: AMPK. COX. NO. Potassium channel. Vascular tone.

Geliş Tarihi: 01.Ekim.2021

Kabul Tarihi: 01.Aralık.2021

Dr. Serdar ŞAHINTÜRK

Bursa Uludağ Üniversitesi, Tıp Fakültesi,

Fizyoloji Anabilim Dalı,

Bursa.

Tel: 022429540 22/30

E-posta: ssahinturk@uludag.edu.tr

Yazarların ORCID Bilgileri:

Serdar SAHINTÜRK: 0000-0002-7612-0055

Naciye İ̧̧BíL: 0000-0002-8792-2555
Damar tonusu bir vasküler yapının maksimum genişlemiş durumuna kıyasla o andaki kasılma derecesini ifade etmektedir. Her bir damar yatağının uyarılmamış durumdaki damar gerimi ise bazal damar tonusu olarak tanımlanabilir. Damar tonusu doku kan akımının düzenlenmesini sağlayan çok sayıdaki ekstrensek ve intrensek faktörün karşılıklı ve sürekli etkileşimi ile düzenlenmektedir. Ekstrensek faktörler nöral ve hümoral etkenlerden oluşmaktadır. İntrensek faktörler ise doku faktörleri, parakrin hormonlar, endotelyal ve miyojenik mekanizmaları kapsamaktadır. Nitrik oksit $(\mathrm{NO})$, atrial natriüretik peptid ve prostaglandin $\mathrm{I}_{2}$ $\left(\mathrm{PGI}_{2}\right)$ gibi bazı faktörler damar geriminin azalmasına ve damarın genişlemesine yani vazodilatasyona neden 
olurken, fenilefrin, anjiyotensin II, tromboksan $\mathrm{A}_{2}$ $\left(\mathrm{TxA}_{2}\right)$ ve serotonin gibi diğer bazı faktörler damar gerimini artırarak damarın daralmasına yani vazokonstriksiyona neden olmaktadır. Öte yandan sempatik sinir sisteminin aktivasyonu genellikle vazokonstriksiyona buna karşın hipoksi ise vazodilatasyona neden olmaktadır. Histamin ve bradikinin gibi bazı faktörler ise damar gerimini artırıcı veya azaltıcı etki gösterebilmektedir ${ }^{1,2}$.

Vasküler tonus düzenleyici faktörler sonuç olarak damar düz kas hücrelerindeki aktin-miyozin etkileşimini düzenlemek için çeşitli sinyal yolaklarının aktivitelerini değiştirerek etkilerini göstermektedir. $\mathrm{Bu}$ sinyal ileti yolaklarının bazı ilaçlarla aktive veya inhibe edilmesi kardiyovasküler hastalıkların tedavisinde yaygın olarak kullanılan bir yöntem olduğundan vasküler fonksiyonlarla ilişkili sinyal mekanizmalarının anlaşılması ve her bir damar yatağındaki olası rollerinin belirlenmesi oldukça önemlidir. Daha önceki çalş̧malarda birçok vazoaktif maddenin meydana getirdiği vasküler kasılma ve gevşeme yanıtlarında endotelyal NO sentaz (eNOS)/NO, mitojenle aktive edilen protein kinaz (MAPK), adenozin monofosfat ile aktive olan protein kinaz (AMPK), siklooksijenaz (COX) ve apelin reseptörü (APJ) sinyal ileti yolakları ile potasyum kanallarının rol oynadığı belirlenmiştir. Önceki çalışmalarda elde edilen veriler vasküler tonusun düzenlenmesinde oldukça önemli olduğu gözlenen bu mekanizmaların bazal damar tonusunun düzenlenmesine de katkıda bulunabileceğini düşündürmektedir. Buna karşın bu konuyu detaylı bir şekilde araştıran bir çalışmaya rastlanmamıştır. $\mathrm{Bu}$ çalışmanın amacı eNOS)/NO, MAPK, AMPK, COX ve APJ sinyal ileti yolakları ile potasyum kanallarının bazal vasküler tonus regülasyonundaki fonksiyonel etkilerini sıçan torasik aort modelinde izole organ banyosu yöntemini kullanarak araştırmaktır.

\section{Gereç ve Yöntem}

\section{Etik Onay ve Deney Hayvanlarl}

Bursa Uludağ Üniversitesi Hayvan Deneyleri Yerel Etik Kurulu'ndan 15.06.2021 tarih ve 2021-08/4 say1l etik onay alındı. Çalışmada Bursa Uludağ Üniversitesi Deney Hayvanları Yetiştirme ve Araştırma Birimi'nden temin edilen 12 haftalık 20 adet Wistar Albino erkek sıçan kullanıldı. Sıçanlar her bir kafeste 4-6 adet olacak şekilde, $22 \pm 2{ }^{\circ} \mathrm{C}$ de, 12 saat aydınlık / 12 saat karanlık döngüsünde tutuldu. Ad libitum olarak yem ve su alımı sağlandı.

\section{İole Organ Banyosu Deneyleri}

Çalışma 6 ana grup olarak planlandı. 1- N $\omega$-Nitro-Larginin metil ester (L-NAME) grubu: eNOS/NO sinyal yolağının bazal damar tonusunun düzenlenmesindeki rolü araştırıldı. 2- İndometazin grubu: COX sin- yal yolağının (prostanoidlerin) bazal damar tonusunun düzenlenmesindeki rolü araştırıldı. 3- U0126 grubu: MAPK sinyal yolağının bazal damar tonusunun düzenlenmesindeki rolü araştırıldı. 4- Dorsomorfin grubu: AMPK sinyal yolağının bazal damar tonusunun düzenlenmesindeki rolü araştırıldı. 5- F13A grubu: APJ sinyal yolağının bazal damar tonusunun düzenlenmesindeki rolü araştırıldı. 6- Tetraetilamonyum (TEA) grubu: Potasyum kanallarının bazal damar tonusunun düzenlenmesindeki rolü araştırıldı.

Siçanlar anestezi uygulanmadan dekapite edildi. Torakoabdominal bölgeleri dikkatli bir şekilde eksize edilen sıçanların torasik aortları hızlı bir şekilde çıkarıldı. Torasik aort dokuları, soğuk Krebs solüsyonu içeren Petri kaplarına yerleştirildi. Perivasküler dokulardan dikkatlice arındırılan damarlardan $4 \mathrm{~mm}$ uzunluğunda damar halkaları hazırlandı. Bir sıçanın torasik aortundan 4 adet damar halkasi elde edildi (her bir damar halkası $\mathrm{n}=1$ ). Vasküler halkalar izole organ banyosu sistemindeki (MAY IOBS99, Commat Ltd., Ankara) cam banyo haznelerine çelik damar asma aparatları ve cerrahi iplik kullanılarak yerleştirildi. Rezervuarlar ve banyo hazneleri Krebs solüsyonu (Tablo I) ile dolduruldu. Dokuların maruz kaldığ 1 sicaklık, çift çeperli sistemde sürekli olarak dolaşan sıcak distile su ile, $37{ }^{\circ} \mathrm{C}$ 'de sabit tutuldu. Krebs solüsyonu içerisindeki dokular \% $95 \mathrm{O}_{2}$ - \% $5 \mathrm{CO}_{2}$ gaz karışımı ile sürekli olarak gazlandırıldı ve $\mathrm{pH}$ 7,4 olarak ayarlandı. İlk 30 dakikanın ardından dinlenim gerimi 1 gram olarak ayarlandı. Daha sonra dokuların metabolik ve fizyolojik olarak dengelenmesi için 1 saat daha beklendi. Bu süreç boyunca banyo haznelerindeki Krebs solüsyonu metabolik son ürünlerin uzaklaştırılması ve içerik konsantrasyonunun yeterli düzeyde tutulabilmesi amaciyla her 15 dakikada bir yenilendi. Vasküler halkalardaki gerim değişiklikleri izometrik kuvvet transdüserleri (MAY FDT05) ile tespit edildi ve bilgisayar yazılımı (BIOPAC MP36) ile kaydedildi.

Tablo I. İlaçlar, kullanım amaçları ve dozları.

\begin{tabular}{|l|l|c|}
\hline Madde & Kullanım amacı & Doz \\
\hline F13A & APJ reseptör antagonisti & $10^{-7} \mathrm{M}$ \\
\hline L-NAME & eNOS inhibitörü & $10^{-3} \mathrm{M}$ \\
\hline U0126 & MAPK kinaz 1-2 inhibiẗrü & $1,5 \mu \mathrm{M}$ \\
\hline İndometazin & Nonselektif COX 1-2 inhibitörü & $5 \mu \mathrm{M}$ \\
\hline Dorsomorfin & AMPK inhibitörü & $10 \mu \mathrm{M}$ \\
\hline TEA & Nonselektif potasyum kanal inhibitörü & $1 \mathrm{mM}$ \\
\hline
\end{tabular}

Sinyal ileti yolaklarının ve potasyum kanallarının bazal damar tonusuna etkisini belirlemek için dengelenme periyodu sonrasinda dinlenim durumundaki damar halkalarından 10 dakikalık süredeki gerim değerlerinin kaydı alındı. Sonrasında her bir grup için ayrı ayrı sinyal yolak inhibitörleri F13A $\left(10^{-7} \mathrm{M}\right)$, LNAME $\left(10^{-3} \mathrm{M}\right)$, dorsomorfin (Compound $\left.\mathrm{C} ; 10 \mu \mathrm{M}\right)$, TEA (1 mM), U0126 $(1,5 \mu \mathrm{M})$ veya indometazin $(5$ $\mu \mathrm{M})$ uyguland. İnhibitörlerin etkilerini tam olarak 
gösterebilmeleri için 30 dakika beklendi ve sonrasında 10 dakikalık süredeki damar gerimlerinin kaydı alındı. İnhibitör madde uygulanmadan önceki 10 dakikalık kayıtta elde edilen bazal gerim değerleri kontrol grubu olarak kullanıldı. Kontrol grubundaki gerim değerleri \% 100 olarak kabul edildi. İnhibitör maddelerin uygulanmasından sonraki 30 dakikalık kaydı takiben elde edilen 10 dakikalık gerim değerleri kontrol grubu ile karşılaştırıldı. Damar halkaları yıkanarak belirtilen protokol tekrar edildi. Her bir grup aynı deney hayvanından elde edilen damar halkaları ile tamamlandı. Bu şekilde araştırılan sinyal ileti yolaklarının ve potasyum kanallarının bazal damar tonusuna etkisi belirlendi.

\section{İlaçlar}

Bu çalışmada kullanılan tüm kimyasal maddeler ve ilaçlar Sigma-Aldrich/Merck firmasından temin edildi. İlaç dozları literatüre uygun olarak belirlendi (Tablo II). İlaçlar kullanım talimatlarına göre hazırlandı. F13A, L-NAME ve TEA distile su içerisinde çözüldü. Dorsomorfin, U0126 ve indometazin dimetil sülfoksit (DMSO) içerisinde çözüldü. Krebs çözeltisindeki son DMSO konsantrasyonu \% 0,1'i geçmedi ve DMSO vasküler düz kas kasılmasını veya gevşemesini etkilemedi.

Tablo II. Krebs solüsyonunun içeriği.

\begin{tabular}{|l|c|}
\hline Madde & Molarite (mM) \\
\hline $\mathrm{CaCl}_{2} \cdot 2 \mathrm{H}_{2} \mathrm{O}$ & 2,5 \\
\hline $\mathrm{NaCl}$ & 118 \\
\hline $\mathrm{KCl}$ & 4,8 \\
\hline $\mathrm{KH}_{2} \mathrm{PO}_{4}$ & 1,2 \\
\hline $\mathrm{C}_{6} \mathrm{H}_{12} \mathrm{O}_{6} \cdot \mathrm{H}_{2} \mathrm{O}$ & 11 \\
\hline $\mathrm{NaHCO}_{3}$ & 25 \\
\hline $\mathrm{MgSO}_{4} \cdot 7 \mathrm{H}_{2} \mathrm{O}$ & 1,2 \\
\hline
\end{tabular}

\section{Istatistiksel Analiz}

İstatistiksel analiz için SPSS (IBM SPSS Statistics 23) programı kullanıldı. Elde edilen veriler, inhibitör madde uygulamasından önceki 10 dakikalık periyotta elde edilen bazal gerim değerlerinin yüzdesi olarak ortalama \pm standart hata (ort. $\pm \mathrm{SH})(\mathrm{n}=8)$ şeklinde ifade edildi. İnhibitör madde uygulamasından önceki (kontrol $=\% 100$ ) ve sonraki periyotta elde edilen yüzde gerim değerleri karşılaştırıldı. İkili grupların karşılaştırılmaları için eşleştirilmiş örneklem $\mathrm{T}$ testi uyguland1. 0,05'ten küçük olan p değerleri istatistiksel olarak anlamlı kabul edildi.

\section{Bulgular}

Kontrol gruplarının yüzde gerim değerleri $\% 100$ olarak kabul edildi. İnhibitör madde uygulamasının öncesindeki ve uygulamadan 30 dakika sonrasındaki 10'ar dakikalık periyodlardaki yüzde gerim değerleri karşılaştırıldı. L-NAME grubunun yüzde gerim değerleri $(136,20 \pm 3,94)$ kontrol grubunun yüzde gerim değerlerinden istatistiksel olarak anlamlı düzeyde daha yüksek bulundu ( $p<0,001)$. İndometazin grubunun yüzde gerim değerleri $(91,90 \pm 2,74)$ kontrol grubunun yüzde gerim değerlerinden istatistiksel olarak anlamlı düzeyde daha düşük bulundu $(\mathrm{p}<0,05)$. Kontrol grubunun yüzde gerim değerleri ile U0126 grubunun yüzde gerim değerleri $(99,30 \pm 4,69)$ arasında istatistiksel olarak anlamlı düzeyde bir fark bulunmadı $(\mathrm{p}>$ $0,05)$. Dorsomorfin grubunun yüzde gerim değerleri $(94,84 \pm 3,88)$ kontrol grubunun yüzde gerim değerlerinden istatistiksel olarak anlamlı düzeyde daha düşük bulundu ( $p<0,05)$. Kontrol grubunun yüzde gerim değerleri ile F13A grubunun yüzde gerim değerleri $(98,23 \pm 2,82)$ arasında istatistiksel olarak anlamlı düzeyde bir fark bulunmadi $(\mathrm{p}>0,05)$. TEA grubunun yüzde gerim değerleri $(108,04 \pm 4,53)$ kontrol grubunun yüzde gerim değerlerinden istatistiksel olarak anlamlı düzeyde daha yüksek bulundu $(\mathrm{p}<0,01)$ (Şekil 1).

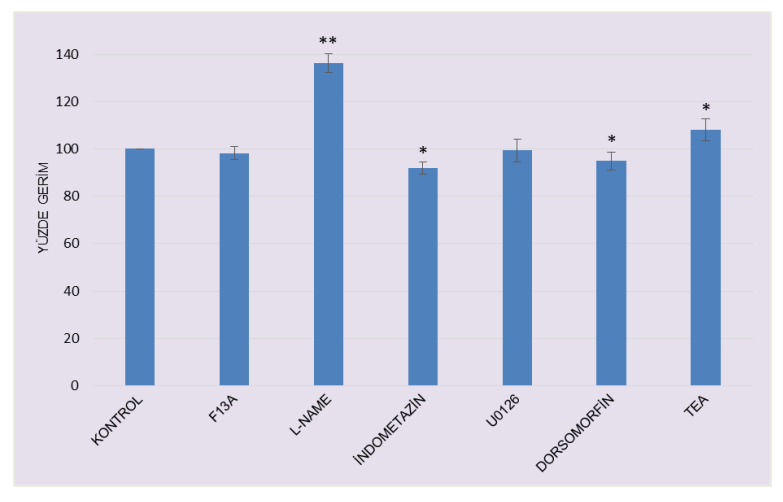

Şekil 1.

Sinyal ileti yolakları ve potasyum kanallarının sıçan torasik aortundaki bazal damar tonusuna etkileri. Veriler ortalama \pm standart hata şeklinde ifade edilmiştir. Her bir grupta $n=8$. *: $p<0,05$. **: $p<$ 0,001 .

\section{Tartışma ve Sonuç}

Bu çalışmada eNOS/NO, COX ve AMPK sinyal ileti yolakları ile potasyum kanallarının sıçan torasik aortundaki bazal damar tonusunun düzenlenmesinde rol oynadıkları belirlenmiştir. Bununla birlikte çalışmamızda MAPK ve APJ sinyal ileti yolaklarının sıçan torasik aortundaki bazal vasküler tonus regülasyonuna katkıda bulunmadıkları sonucu elde edilmiştir.

Çalışmamızda endotel bağımlı vazodilatatör mekanizmaların en önemlisi olan eNOS/NO sinyal yolağ1nın sıçan torasik aortundaki bazal damar tonusunun düzenlenmesinde rol oynadığı belirlenmiştir. Elde ettiğimiz bu sonuç daha önceki çalışmalarda elde edilen verilerle uyumludur. Endotel kaynaklı faktörle- 


\section{S. Şahintürk ve N. İşbil}

rin vasküler tonus düzenlenmesinde çok önemli bir rol oynadığ1 bilinmektedir. $\mathrm{Bu}$ faktörlerden başlıcaları eNOS/NO sinyal yolağının aktiflenmesi ile üretilen NO ve COX yolağı üzerinden üretilen, başlıca PGI2 (prostasiklin) olmak üzere, prostaglandinlerdir. NO, solübl guanilat siklazı aktive ederek siklik guanozin monofosfat oluşumunu uyarmaktadır. Sonrasında uyarılan protein kinaz $G$ ve aktifleşen birçok mekanizma ile sitoplazmik kalsiyum konsantrasyonunun ve kontraktil elemanların kalsiyum duyarlılığının azalmaS1 sonucunda vazodilatasyon meydana gelmektedir ${ }^{3}$. $\mathrm{Bu}$ mekanizmayı aktifleştiren veya doğrudan vücuda NO sağlayan ilaçlar özellikle artmış vazoreaktivite ile ilişkili hipertansiyon gibi hastalıkların tedavisinde yaygın olarak kullanılmaktadır. Çalışmamızda elde edilen veriler L-NAME uygulanarak oluşturulan eNOS inhibisyonu sonrasında sıçan torasik aortundaki bazal damar tonusunda istatistiksel olarak anlaml düzeyde bir artış olduğunu göstermektedir. Bu durum sıçan torasik aortundaki bazal tonus düzenlenmesinde eNOS/NO sinyal yolağının önemli bir rolü olduğunu düşündürmektedir. Daha önceki çalışmalar eNOS/NO sinyal yolağının birçok vazoaktif maddenin endotel bağımlı vazodilatatör etkisine aracılık ettiğini göstermektedir. Son zamanlarda yaptığımız bir çalışmada apelinin sıçan torasik aortundaki vazorelaksan etkisinde eNOS/NO sinyal yolağının önemli bir katkısının olduğu belirlenmiştir ${ }^{4}$. Ayrıca nesfatin-1 ve resveratrol gibi vazoaktif maddelerin vazodilatatör etkilerinde de eNOS/NO sinyal yolağının rolü olduğu rapor edilmiş$\operatorname{tir}^{5,6}$. Bu sonuçlar vazoaktif maddelerin vazorelaksan etki mekanizmalarında eNOS/NO sinyal yolağının oldukça önemli bir yer tuttuğunu göstermektedir. Bu çalışmada elde ettiğimiz bulgular daha önceki çalışmalarla uyumluluk göstermekte ve sıçan torasik aortundaki bazal damar tonus regülasyonunda önemli faktörlerden birinin de eNOS/NO sinyal yolağı olduğuna işaret etmektedir. Öte yandan elabela gibi bazı vazoaktif maddelerin vazodilatatör etkisinin ise eNOS/NO sinyal yolağından bağımsız olarak gerçekleştiği rapor edilmiştir ${ }^{7}$. Bu nedenle vasküler tonus regülasyonuna farklı etken maddelerin farklı mekanizmalarla aracılık ettiği düşünülmektedir. Ayrıca çalışmalarda tercih edilen damar yatağının türü de elde edilen sonuçları etkileyebilmekte ve her bir damar yatağının ayrı olarak araştırılması gerekmektedir.

Endotel bağımlı önemli vazodilatatör mekanizmalardan bir diğeri ise COX sinyal yolağıdır. Bu çalışmada elde ettiğimiz veriler COX sinyal yolağının sıçan torasik aortundaki bazal damar tonus düzenlenmesinde rol aldığını göstermektedir. COX sinyal yolağının ürünü olan prostanoidler, fizyolojik ve patolojik uyarıma yanıt olarak vazokonstriksiyona veya vazodilatasyona neden olabilmektedir ${ }^{8}$. Prostaglandinlerin akım aracılı olarak arteriollerde meydana gelen vazodilatasyonda rol oynadığı bildirilmiştir ${ }^{9}$. Prostanoid aracılı vazodilatatör etkinliğin eNOS/NO gibi diğer endotel kaynaklı vazodilatatör yolakların baskılandığı durumlarda daha belirgin olduğu ve nörohümoral faktörlerden çok kan akımı ile ilişkili nedenlerle ortaya çıktığı ileri sürülmektedir ${ }^{10,11}$. Prostanoidler arasında özellikle $\mathrm{PGI}_{2}, \mathrm{PGD}_{2}$ ve $\mathrm{PGE}_{2}$ 'nin genellikle vazodilatatör etkinlik gösterdiği bildirilmiştir. $\mathrm{PGH}_{2}$, $\mathrm{PGF}_{2 \alpha}$ ve $\mathrm{TxA}_{2}$ 'nin ise genellikle vazokonstriktör etkinlik gösterdiği belirlenmiştir ${ }^{12}$. Özellikle $\mathrm{PGI}_{2}$, COX sinyal yolağının neden olduğu vazodilatasyonda oldukça önemlidir. Güçlü bir vazodilatatör olan $\mathrm{PGI}_{2}$ 'nin farelerde ve insanlarda koroner kan akımının düzenlenmesinde rol aldığı bildirilmiştir ${ }^{13,14}$. $\mathrm{PGI}_{2}$ ve sentetik analoglarının çeşitli potasyum kanallarının açılması sonucunda hiperpolarizasyona neden olarak vazorelaksasyona neden olduğu ileri sürülmektedir ${ }^{15,16}$. $\mathrm{PGE}_{2}$ damar yatağ ${ }_{1}$ ve ilgili reseptör alt tipine bağlı olarak büyük kan damarlarını genişletebilmekte veya daraltabilmektedir ${ }^{8,12}$. $\mathrm{PGD}_{2}$ injeksiyonunun fare kulak damarlarında doza bağımlı bir şekilde vazodilatasyona neden olduğu belirlenmiştir ${ }^{8}$. $\mathrm{PGF}_{2 \alpha}$ 'nın siçan femoral arter şeritlerinde vazokonstriksiyona neden olduğu, benzer şekilde hamster aortunda da vazokonstriktör etki gösterdiği bildirilmiştir ${ }^{17}$. TxA ${ }_{2}$ 'nin, koroner ve serebrovasküler iskemide rol oynayan güçlü bir vazokonstriktör olduğu gösterilmiştir ${ }^{18}$. Tüm bu sonuçlar COX sinyal yolağının ve prostanoidlerin bazal damar tonusunun düzenlenmesine katkıda bulunabileceğini göstermektedir. Buna karşın COX sinyal yolağının sıçan torasik aortundaki bazal damar tonus regülasyonundaki rolünün araştırıldığı bir çalışmaya rastlanmamıştır. Çalışmamızda elde edilen bulgular nonselektif bir COX inhibitörü olan indometazin uygulamasının sıçan torasik aortundaki bazal tonusu istatistiksel olarak anlamlı düzeyde azalttığını göstermektedir. Bu veri prostanoidlerin bazal vasküler tonus regülasyonunda önemli bir rol oynadığını ve sıçan torasik aortunda da etkin olduğunu düşündürmektedir. Öte yandan damar yatağının türüne göre vasküler tonus düzenleyici mekanizmaların etkinliği değişebilmektedir. Örneğin insan internal torasik arter örneklerinde apelinin prostanoid aracılı vazodilatatör etkisinden bahsedilirken, insan hepatik ve mezenterik arter örneklerinde apelin aracılı vazorelaksan etkinin prostanoidlerden bağımsız olarak meydana geldiği bildirilmiştir $^{19,20}$. Bu nedenle her bir damar yatağındaki bazal damar tonusunu düzenleyici faktörlerin değişkenlik gösterebileceği düşünülmektedir. Bu çalışmada elde edilen bulgularla prostanoidlerin sıçan torasik aortundaki bazal damar tonusunun düzenlenmesine rolü olduğu gösterilmiş olmakla birlikte çalışmamızda nonselektif bir COX inhibitörü olan indometazin kullanılmış olması nedeniyle bu düzenlemeye hangi prostanoid alt tipinin ne ölçüde katkıda bulunduğu belirlenememiştir. Sonraki çalışmalarda spesifik COX ve prostaglandin sentaz inhibitörleri kullanılarak bazal vasküler tonus regülasyonunda rol oynayan prostanoid alt tipleri ve katkı düzeylerinin belirlenebileceği düşünülmektedir. 


\section{Vasküler Tonus Regülasyonu}

Çalışmamızda elde ettiğimiz bir diğer önemli sonuç da AMPK sinyal yolağının sıçan torasik aortundaki bazal vasküler tonus regülasyonuna katkıda bulunduğudur. Damar düz kas ve endotel hücreleri ile perivasküler adipöz dokudan kaynaklanabilen AMPK'nın vasküler tonusun düzenlenmesinde rolü olduğu ileri sürülmektedir $^{21}$. AMPK vasküler endotelyal hücrelerdeki eNOS aktivitesini uyarmakta ve bunun sonucunda endotel bağımlı ve NO aracılı olarak vazodilatasyon meydana gelmektedir ${ }^{22}$. Ayrıca AMPK'nın endotelden bağımsız vazodilatasyonda da rolü olduğu bildirilmiştir. Bu etki vasküler düz kas hücresindeki miyozin hafif zincir kinazın $\mathrm{Ca}^{+2}$ duyarlılığının azalması yolu ile sağlanmaktadır $^{23}$. Daha önceki çalışmalar AMPK sinyal yolağının vazorelaksan etkilere aracılık ettiğini göstermektedir. AMPK aktivasyonunun spontan hipertansif sıçanlarda NO aracılı vazodilatasyona neden olduğu gösterilmiştir ${ }^{24}$. AMPK'nın fare aort düz kasının endotelden bağımsız gevşemesinde rolü olduğu bildirilmiştir. AMPK aktivatörü 5-aminoimidazol-4karboksamid-1- $\beta$-D-ribofuranosid (AICAR)'in arteryel vazodilatasyona neden olduğu ve bu etkinin AMPK'dan yoksun farelerde büyük oranda azaldığ 1 belirlenmiştir ${ }^{25}$. AICAR'ın spontan hipertansif sıçanlarda kan basıncını hızla düşürdüğü gösterilmiştir ${ }^{24}$. Obez sıçanlarda AICAR uygulamasına bağlı olarak sistolik kan basıncında düşüş görülmüştür ${ }^{26}$. Daha selektif bir AMPK aktivatörü olan A769662'nin direnç arterlerinde endotelden bağımsız gevşemeye neden olduğu belirlenmiştir ${ }^{27}$. Tüm bu veriler AMPK'nın vasküler tonus düzenlenmesinde önemli bir rolü olduğunu açıç̧a ortaya koymakla birlikte şimdiye kadar AMPK sinyal yolağının bazal damar tonusunun düzenlenmesinde rol oynayıp oynamadığını gösteren bir çalışmaya rastlanmamıştır. Çalışmamızın sonuçları AMPK inhibitörü dorsomorfin uygulamasının sıçan torasik aortundaki bazal damar tonusunu istatistiksel olarak anlamlı düzeyde azalttığını göstermiştir. Elde edilen bu veri daha önceki çalışmalarda gösterilen AMPK aracılı vazoaktif etkilerle birbirini tamamlamaktadır ve AMPK sinyal yolağı ile ilişkili mekanizmaların bazal damar tonusunun düzenlenmesine önemli bir katkısının olduğunu düşündürmektedir. Son zamanlarda yaptığımız bir çalışmada elde ettiğimiz sonuçlar da bu çalışmadaki bulgumuzla aynı doğrultudadır. Apelinin sıçan torasik aortundaki vazodilatatör etkisini gösterdiğimiz çalışmamızda apelinin vasküler fonksiyonel etkilerine aracılık eden önemli bir mekanizmanın da AMPK sinyal yolağı olduğu belirlenmiştir ${ }^{4}$. Bu verilerin tamamı dikkate alındığında vasküler tonus regülasyonunda önemli bir faktörün de AMPK sinyal yolağı olduğu ve bu mekanizmanın hem uyarılmış hem de bazal şartlardaki vasküler tonus regülasyonunu etkilediği sonucuna ulaşılmaktadır.

Araştırmış olduğumuz önceki sinyal ileti mekanizmalarının aksine MAPK ve APJ sinyal ileti yolaklarının sıçan torasik aortunun bazal tonusunun düzenlenmesinde rol oynamadıkları çalışmamızda ulaşılan bir diğer önemli sonuçtur. MAPK sinyal yolağının vasküler kontraktil fonksiyonlarla ilişkili olduğu düşünülmektedir. İzole edilmiş kan damarlarındaki bazı $\mathrm{G}$ protein kenetli reseptörlerin aktivasyonuna yanıt olarak meydana gelen kasılmanın MAPK sinyal yolağında aktifleșen ekstraselüler sinyal düzenleyici kinaz (ERK) aktivitesindeki artış ile ilişkili olduğu ve ERK inhibisyonunun kan damarlarının kasılma derecesini azalttığ 1 rapor edilmiştir ${ }^{28,29}$. Kan damarlarındaki gerilme sonucunda meydana gelen kasılmanın ERK aktivitesindeki artışla bağlantılı olduğu bildirilmiştir ${ }^{30}$. ERK'nin yaban gelinciği aortundaki $\alpha 1$-adrenoseptör aracılı kasılmada ve domuz palmar lateral venindeki $\alpha 2$-adrenoseptör aracılı kasılmada rol oynadığı gözlenmiştir $^{29,31}$. Başka bir çalışmada ERK'nin kan damarlarında miyozin hafif zincir kinazı aktive ederek kasılmaya neden olduğu bildirilmiştir ${ }^{32}$. Domuz palmar lateral veni kullanılan bir çalışmada ERK inhibisyonunun miyozin hafif zincir fosforilasyonunda azalmaya neden olduğu gösterilmiştir ${ }^{33}$. Daha önceki çalışmalarda elde edilen veriler MAPK sinyal yolağının vasküler kontraktil fonksiyonların önemli bir düzenleyicisi olduğuna işaret etmektedir. Buna karşın bazal damar tonus regülasyonunda MAPK sinyal yolağının rolü olup olmadı̆̆ şimdiye kadar gösterilmemiştir. Bizim çalışmamızda daha önceki çalışmalardan farklı olarak, MAPK sinyal yolağının U0126 kullanılarak inhibe edilmesi sonucunda sıçan torasik aortundaki bazal gerim değerlerinde istatistiksel olarak anlamlı bir değişiklik oluşmadığı belirlenmiştir. $\mathrm{Bu}$ sonuç önemli kardiyovasküler etkilere aracılık etmesine rağmen MAPK sinyal yolağının sıçan torasik aortundaki bazal vasküler tonus regülasyonunda önemli bir yeri olmadığını düşündürmektedir. Güncel bir çalışmada MAPK sinyal yolağının önemli bir vazoaktif madde olan irisinin sıçan torasik aortundaki vazorelaksan etkisine aracıllk ettiği bildirilmiştir ${ }^{34}$. Buna karşın elabela ve apelin gibi bazı güncel ve önemli vazoaktif peptidlerin fare koroner arteri ve sıçan aortlarındaki vazodilatatör etkilerinde MAPK sinyal yolağının anlamlı düzeyde bir etkisi olmadığı rapor edilmiştir $^{4,35}$. Bu bulguların tümü MAPK sinyal yolağının bazal damar tonus düzenlenmesinden daha çok çeşitli vazoaktif maddelerin vasküler fonksiyonel etkilerine aracılık etmede daha önemli bir role sahip olduğu düşündürmektedir. Bununla birlikte çalışmalarda kullanılan damar yatakları, uygulanan deneysel prosedürler ve kullanılan vazoaktif maddelerin tipi elde edilen sonuçların önemli belirleyicileridirler.

APJ sinyal yolağı apelinerjik sistemin endojen ligandları olan apelin ve elabela'nın fizyolojik etkilerine aracılık etmesi nedeniyle oldukça önemlidir ${ }^{36}$. Bu etkilerden en belirginlerinden birisi de vazodilatasyondur. Özellikle apelinin APJ'ye bağlandıktan sonra eNOS/NO sinyal yolağı, prostanoidler ve potasyum kanallarının aktivasyonu ile vazodilatasyona neden olduğu ileri sürülmektedir ${ }^{37}$. Birçok çalışmada gösterilen apelin ve elabela aracılı antihipertansif etki de bu 


\section{S. Şahintürk ve N. İşbil}

endojen peptidlerin vazodilatatör etkileri ile uyumludur $^{38,39}$. Bu veriler apelin ve elabelanın hipertansif hastalıklar için terapötik potansiyel taşıdığını ve bu maddelerin vazorelaksan etkisine aracılık eden APJ sinyal yolağının vasküler tonus düzenlenmesinde önemli bir mekanizma olabileceğini düşündürmektedir. Önceki çalışmalar APJ reseptör antagonisti uygulamasının apelinin vazorelaksan etkisini tümüyle ortadan kaldırdığını ortaya koymuştur ${ }^{4}$. Bazal şartlardaki damar tonusu üzerinde APJ sinyal yolağının belirleyici bir etkisi olup olmadığ 1 ise henüz gösterilmemiştir. Çalışmamızda APJ reseptör antagonisti F13A uygulaması sonrasında sıçan torasik aortundaki bazal damar geriminde istatistiksel olarak anlamlı düzeyde bir değişiklik oluşmadığı görülmüştür. Bu veri birçok kardiyovasküler fizyopatolojik etkisi olan APJ sinyal yolağının fizyolojik koşullarda sıçan torasik aortunun bazal tonusu üzerinde önemli bir etkisinin olmadığını göstermektedir. Buna karşın daha önceki çalışmalar apelin ve elabela gibi vazoaktif maddelerin vasküler fonksiyonel etkilerini APJ sinyal yolağı üzerinden ortaya koyduğunu göstermektedir ${ }^{4,36}$. $\mathrm{Bu}$ nedenle MAPK sinyal yolağına benzer şekilde APJ sinyal yolağının da bazal şartlardan daha çok vazoaktif maddeler tarafından uyarılan vasküler tonus regülasyonuna katkıda bulunan bir mekanizma olduğu düşünülmektedir. Ayrıca çalışmamızda hem U0126 hem de F13A tek doz olarak kullanılmış ve daha yüksek dozlarda sıçan torasik aortunun bazal gerimini etkileyip etkilemeyecekleri araştırılmamıştır. Bundan dolayı daha sonraki çalışmalarda bu inhibitör maddelerin farklı dozlarının kullanılarak ilgili sinyal yolaklarının bazal damar tonus düzenlemesindeki olası rollerinin daha detaylı araştırılması gerektiği düşünülmektedir.

Son olarak çalışmamızda potasyum kanallarının sıçan torasik aortundaki bazal vasküler tonus regülasyonunda önemli bir faktör olduğu sonucuna ulaşılmıştır. Potasyum kanallarından hücre dışına potasyum akışı membran potansiyelinin belirlenmesinde çok önemli bir faktördür. Bu nedenle potasyum kanalları vasküler tonus düzenlenmesinde kritik role sahiptir. Potasyum kanallarının aktive olması genellikle hiperpolarizasyona, inhibe olması ise depolarizasyona neden olmaktadır. $\mathrm{Bu}$ durum voltaj kapılı kalsiyum kanallarının açılıp kapanmasını kontrol ederek vasküler tonus üzerinde düzenleyici olarak işlev görmektedir ${ }^{40,41}$. Membran potansiyelinin sadece voltaj kapılı $\mathrm{Ca}^{+2}$ kanallarının aktivitesini düzenlemekle kalmadığı, aynı zamanda hücre içi depolardan $\mathrm{Ca}^{+2}$ salımını ve kontraktil aparatın $\mathrm{Ca}^{+2}$ duyarlılığını da etkilediği bildirilmiştir ${ }^{42,43}$. Böylece, membran potansiyelini belirlemedeki baskınlıkları nedeniyle, $\mathrm{K}^{+}$kanalları vasküler tonusun belirlenmesi ve düzenlenmesinde kilit bir rol oynamaktadır. Vasküler düz kasta çeşitli $\mathrm{K}^{+}$kanalı alt tiplerinin işlevsel olduğu bildirilmiştir. Bunlardan başlıcaları ATP'ye duyarlı, $\mathrm{Ca}^{+2}$ ile aktiflenen, voltaja duyarlı, 2 porlu ve içeri doğrultucu $\mathrm{K}^{+}$kanallarıdır $^{40,41}$. TEA seçici olmayan bir potasyum kanal inhibitörü olup bu kanalların birçoğuna etki edebilmekte ve vasküler kasılma-gevşeme çalışmalarında yaygın olarak kullanılmaktadır ${ }^{41}$. Bizim çalışmamızda TEA uygulaması sonrasında sıçan torasik aortundaki bazal gerim değerlerinde istatistiksel olarak anlamlı düzeyde artış olduğu sonucuna ulaşılmıştır. Bu sonuç vasküler tonus düzenlenmesinde kritik bir role sahip olan potasyum kanallarının bu etkisinin sıçan torasik aort modelinde de bazal şartlardaki vasküler tonus üzerinde etkin olduğunu göstermektedir. Elde ettiğimiz bu bulgu daha önceki çalışmalarda elde edilen ve vazoaktif maddelerle uyarılan vasküler fonksiyonel etkilerde potasyum kanallarının rolü olduğu sonucu ile uyumludur. Son zamanlarda yapılan bir çalışma irisinin vazodilatatör etkisinde potasyum kanallarının aktivasyonunun önemli bir faktör olduğunu göstermektedir ${ }^{44}$. Benzer şekilde potasyum kanalları resveratrol ve apelin gibi birçok vazoaktif maddenin vazorelaksan etkisine de aracilık etmektedir ${ }^{4,6}$. Tüm bu veriler göstermektedir ki potasyum kanalları hem bazal damar tonusunun hem de vazoaktif maddelerle uyarılmış vasküler tonusun düzenlenmesinde önemli bir etkendir. Çalışmamızda seçici olmayan bir potasyum kanal inhibitörü kullanılması nedeniyle hangi potasyum kanal alt tiplerinin ve ne düzeyde bazal damar tonus regülasyonuna katkıda bulunduğu belirlenememiştir. Daha sonraki çalışmalarda spesifik potasyum kanal alt tip inhibitörleri kullanılarak hangi potasyum kanallarının bazal damar tonus regülasyonunda rol aldığının gösterilebileceği düşünülmektedir.

Çalışmamızın bazı önemli kısıtları bulunmaktadır. Bu kısıtların birisi çalışmamızın in vitro şartlarda yapılmış olmasıdır. Bunun yanında çalışmamızda potasyum kanal aktivasyonunu göstermek amaciyla path clamp tekniği gibi doğrudan ölçüm yöntemleri kullanılmamıştır. Ayrıca elastik bir damar olan aort kullanılmış olması ve musküler arter örnekleri kullanılmamış olması çalışmamızın diğer bir önemli kısıtıdır. Daha sonraki çalışmalarda insan damar örnekleri, hastalık modelleri ve farklı ilaç dozları kullanılarak yeni veriler elde edilebilir. Bununla birlikte protein kinaz $C$ ve Rho kinaz sinyal yolakları gibi diğer önemli mekanizmaların da bazal vasküler tonus regülasyonundaki olası rolleri araştırılabilir.

Sonuç olarak, bu çalışmada elde edilen veriler eNOS/NO, COX ve AMPK sinyal yolakları ile potasyum kanallarının sıçan torasik aortundaki bazal vasküler tonusun düzenlenmesinde önemli rolleri olduğunu düşündürmektedir. Bununla birlikte, MAPK ve APJ sinyal yolaklarının inhibisyonu sıçan torasik aortundaki bazal damar gerimi üzerinde anlamlı düzeyde bir etki göstermemiştir. Bu durum seçilen damar yatağ veya ilaç dozlarından kaynaklanmış olabilir. Artmış vazoreaktivite ile ilişkili birçok hastalığın tedavisi açısından anlaşılması oldukça önemli olan bazal vasküler tonusun fizyolojik regülasyonu çok sayıdaki kompleks mekanizmaların bir sonucudur ve bu çalış- 


\section{Vasküler Tonus Regülasyonu}

mada sadece bazı önemli mekanizmaların etkisi araştırılmıştır. Vasküler fonksiyonel mekanizmalara dair elde edilen yeni veriler literatüre önemli katkılar sağlayacaktır.

\section{Etik Kurul Onay Bilgisi:}

Onaylayan Kurul: Bursa Uludağ Üniversitesi Hayvan Deneyleri Yerel Etik Kurulu

Onay Tarihi: 15.06 .2021

Karar No: 2021-08/4

Araștırmacı Katkı Beyanı: Fikir ve tasarım: S.S.., N.İ.; Veri toplama ve işleme: S.Ş.; Analiz ve verilerin yorumlanması: S.Ş., N.İ.; Makalenin önemli bölümlerinin yazılması: S.Ş., N.İ.

Destek ve Teşekkür Beyanı: Bu makalede yer alan çalışmalar Bursa Uludağ Üniversitesi Tıp Fakültesi Fizyoloji Anabilim Dalı'nın imkanları ile gerçekleștirilmiștir.

Çıkar Çatışması Beyanı: Makale yazarlarının çıkar çatışması beyanı yoktur.

\section{Kaynaklar}

1. Barrett KE, Barman SM, Boitano S, Brooks HL, (eds.). Ganong'un Tibbi Fizyolojisi. 24. baskı. İstanbul: Nobel Tip Kitabevleri; 2015.

2. Hall JE, (ed.). Guyton ve Hall Tibbi Fizyoloji. 13. Bask1. Ankara: Güneș Tıp Kitabevleri; 2017.

3. Zhao Y, Vanhoutte PM, Leung SWS. Vascular nitric oxide: Beyond eNOS. Journal of Pharmacological Sciences 2015;129(2):83-94.

4. Sahinturk S, Demirel S, Ozyener F, Isbil N. [Pyr1]apelin-13 relaxes the rat thoracic aorta via APJ, NO, AMPK, and potassium channels. General Physiology and Biophysics 2021;40(5):427-34

5. Barutcigil A, Tasatargil A. Effects of nesfatin-1 on atrial contractility and thoracic aorta reactivity in male rats. Clinical and Experimental Hypertension 2018;40(5):414-20.

6. Tan CS, Loh YC, Tew WY, Yam MF. Vasorelaxant effect of 3,5,4'-trihydroxy-trans-stilbene (resveratrol) and its underlying mechanism. Inflammopharmacology 2020;28(4):869-75.

7. Wang Z, Yu D, Wang M, Wang Q, Kouznetsova J, Yang R, et al. Elabela-apelin receptor signaling pathway is functional in mammalian systems. Scientific Reports 2015;5:8170.

8. Zhu L, Zhang Y, Guo Z, Wang M. Cardiovascular Biology of Prostanoids and Drug Discovery. Arteriosclerosis, Thrombosis, and Vascular Biology 2020;40;1454-63.

9. Koller A, Kaley G. Prostaglandins mediate arteriolar dilation to increased blood flow velocity in skeletal muscle microcirculation. Circulation Research 1990;67:529-34.

10. Corriu C, Félétou M, Canet E, Vanhoutte PM. Endotheliumderived factors and hyperpolarisations of the isolated carotid artery of the guinea-pig. British Journal of Pharmacology 1996;119:959-64.

11. Zygmunt PM, Plane F, Paulsson M, Garland CJ, Högestätt ED Interactions between endothelium-derived relaxing factors in the rat hepatic artery: focus on regulation of EDHF. British Journal of Pharmacology 1998;124:992-1000.

12. Félétou M, Huang Y, Vanhoutte PM. Endothelium-mediated control of vascular tone: COX-1 and COX-2 products. British Journal of Pharmacology 2011;164(3):894-912.

13. Gutterman DD, Chabowski DS, Kadlec AO, Durand MJ, Freed JK, Ait-Aissa K, Beyer AM. The human microcirculation: regulation of flow and beyond. Circulation Research 2016;118: $157-72$
14. Gwóźdź P, Drelicharz L, Kozlovski VI, Chlopicki S. Prostacyclin, but not nitric oxide, is the major mediator of acetylcholineinduced vasodilatation in the isolated mouse heart. Pharmacological Reports 2007;59:545-52.

15. Corriu C, Félétou M, Edwards G, Weston AH, Vanhoutte PM. Differential effects of Prostacyclin and Iloprost in the isolated carotid artery of the guinea-pig. European Journal of Pharmacology 2001;426:89-94.

16. Félétou M, Vanhoutte PM. Endothelium-dependent hyperpolarizations: past beliefs and present facts. Annals of Medicine 2007;39:495-516.

17. Wong SL, Leung FP, Lau CW, Au CL, Yung LM, Yao X, et al. Cyclooxygenase-2-derived prostaglandin F2alpha mediates endothelium-dependent contractions in the aortae of hamsters with increased impact during aging. Circulation Research 2009;104:228-35.

18. Smith JB, Araki H, Lefer AM. Thromboxane A2, prostacyclin and aspirin: effects on vascular tone and platelet aggregation. Circulation 1980;62(6 pt 2):(V19-V25).

19. Maguire JJ, Kleinz MJ, Pitkin SL, Davenport AP. [Pyr1]apelin13 identified as the predominant apelin isoform in the human heart: vasoactive mechanisms and inotropic action in disease. Hypertension 2009;54(3):598-604.

20. Salcedo A, Garijo J, Monge L, Fernández N, García-Villalón AL, Turrión VS, et al. Apelin effects in human splanchnic arteries. Role of nitric oxide and prostanoids. Regulatory Peptides 2007;144:50-5

21. Verma T, Sinha M, Bansal N, Yadav SR, Shah K, Chauhan NS Plants Used as Antihypertensive. Natural Products and Bioprospecting 2021;11(2):155-84

22. Ewart MA, Kennedy S. AMPK and vasculoprotection. Pharmacology \& Therapeutics 2011;131:242-53.

23. Salt IP, Hardie DG. AMPK, AMP-Activated Protein Kinase: An Ubiquitous Signaling Pathway With Key Roles in the Cardiovascular System. Circulation Research 2017;120(11): 182541.

24. Ford RJ, Teschke SR, Reid EB, Durham KK, Kroetsch JT, Rush JW. AMP-activated protein kinase activator AICAR acutely lowers blood pressure and relaxes isolated resistance arteries of hypertensive rats. Journal of Hypertension 2012;30,72533 .

25. Goirand F, Solar M, Athea Y, Viollet B, Mateo P, Fortin D, et al. Activation of AMP kinase alpha1 subunit induces aortic vasorelaxation in mice. The Journal of Physiology 2007;581:1163-71.

26. Buhl ES, Jessen N, Pold R, Ledet T, Flyvbjerg A, Pedersen SB, et al. Long-term AICAR administration reduces metabolic disturbances and lowers blood pressure in rats displaying features of the insulin resistance syndrome. Diabetes 2002;51:2199-206.

27. Schneider H, Schubert KM, Blodow S, Kreutz CP, Erdogmus S, Wiedenmann M, et al. AMPK dilates resistance arteries via activation of SERCA and $\mathrm{BK}_{\mathrm{Ca}}$ channels in smooth muscle. Hypertension 2015;66:108-16.

28. Banes A, Florian JA, Watts SW. Mechanisms of 5hydroxytryptamine $2 \mathrm{~A}$ receptor activation of the mitogenactivated protein kinase pathway in vascular smooth muscle. Journal of Pharmacology and Experimental Therapeutics 1999;291(3):1179-87.

29. Roberts RE. Role of the extracellular signal-regulated kinase (ERK) signal transduction cascade in $\alpha 2$-adrenoceptormediated vasoconstriction in porcine palmar lateral vein. British Journal of Pharmacology 2001;133(6):859-66.

30. Oeckler RA, Kaminski PM, Wolin MS. Stretch enhances contraction of bovine coronary arteries via an NADPH oxidasemediated activation of the extracellular signal-regulated mitogen-activated protein kinase cascade. Circulation Research 2003;92(1):23-31. 


\section{S. Şahintürk ve N. İşbil}

31. Dessy C, Kim I, Sougnez CL, Laporte R, Morgan KG. A role for MAP kinase in differentiated smooth muscle contraction evoked by $\alpha$-adrenoceptor stimulation. American Journal of Physiology 1998;275(4 Pt 1):C1081-C1086.

32. Klemke RL, Cai S, Giannini AL, Gallagher PJ, de Lanerolle P, Cheresh DA. Regulation of cell motility by mitogen-activated protein kinase. Journal of Cell Biology 1997;137(2):481-92.

33. Roberts RE. The role of Rho kinase and extracellular regulated kinase-mitogen-activated protein kinase in $\alpha 2$-adrenoceptormediated vasoconstriction in the porcine palmar lateral vein. Journal of Pharmacology and Experimental Therapeutics 2004;311(2):742-7.

34. Demirel S, Sahinturk S, Isbil N, Ozyener F. Irisin relaxes rat thoracic aorta: MEK1/2 signaling pathway, $\mathrm{K}_{\mathrm{V}}$ channels, $\mathrm{SK}_{\mathrm{Ca}}$ channels, and $\mathrm{BK}_{\mathrm{Ca}}$ channels are involved in irisin-induced vasodilation. Canadian Journal of Physiology and Pharmacology 2021; doi: 10.1139/cjpp-2021-0500.

35. Perjés Á, Kilpiö T, Ulvila J, Magga J, Alakoski T, Szabó Z, et al. Characterization of apela, a novel endogenous ligand of apelin receptor, in the adult heart. Basic Research in Cardiology 2016;111:2.

36. Isbil N, Sahinturk S, Demirel S. Vascular Functional Effects of the Apelinergic System. Journal of Literature Pharmacy Sciences 2021;10(1):12-20.

37. Rikitake Y. The apelin/APJ system in the regulation of vascular tone: friend or foe?. The Journal of Biochemistry 2020;0(0):1-4
38. Mughal A, O'Rourke ST. Vascular effects of apelin: Mechanisms and therapeutic potential. Pharmacology \& Therapeutics 2018;190:139-47.

39. Yang P, Read C, Kuc RE, Buonincontri G, Southwood M, Torella R., et al. Elabela/Toddler Is an Endogenous Agonist of the Apelin APJ Receptor in the Adult Cardiovascular System, and Exogenous Administration of the Peptide Compensates for the Downregulation of Its Expression in Pulmonary Arterial Hypertension. Circulation 2017;135(12):1160-73.

40. Jackson WF. Ion Channels and Vascular Tone. Hypertension 2000;35(1 Pt 2):173-8.

41. Tykocki NR, Boerman EM, Jackson WF. Smooth Muscle Ion Channels and Regulation of Vascular Tone in Resistance Arteries and Arterioles. Comprehensive Physiology 2017;7(2):485581.

42. Ganitkevich VY, Isenberg G. Membrane potential modulates inositol 1,4,5-trisphosphate-mediated $\mathrm{Ca}^{2+}$ transients in guineapig coronary myocytes. The Journal of Physiology 1993;470:35-44.

43. Okada Y, Yanagisawa T, Taira N. BRL 38227 (levcromakalim)-induced hyperpolarization reduces the sensitivity to $\mathrm{Ca}^{2+}$ of contractile elements in canine coronary artery. NaunynSchmiedeberg's Archives of Pharmacology 1993;347:438-44.

44. Demirel S, Sahinturk S, Isbil N, Ozyener F. Physiological role of $\mathrm{K}^{+}$channels in irisin-induced vasodilation in rat thoracic aorta. Peptides 2022;147:170685. 